\title{
Corrigendum to "Determination of Serum Lost Goodwill Target Proteome in Patients with Severe Traumatic Brain Injury"
}

\author{
Hongming Ji, ${ }^{1}$ Changchen Hu, ${ }^{1}$ Gangli Zhang $\left(\mathbb{D},{ }^{1,2}\right.$ Jinrui Ren, ${ }^{1}$ Yihu Tan, ${ }^{3}$ Wenxiao Sun, ${ }^{3}$ \\ Junwen Wang, ${ }^{4} \mathrm{Jun} \mathrm{Li}^{4}{ }^{4}$ Hongchao Liu, ${ }^{3}$ Ruifan Xie, ${ }^{2}$ Zhipeng Hao, ${ }^{3}$ and Dongsheng $\mathrm{Guo}^{2}$ \\ ${ }^{1}$ Department of Neurosurgery, Shanxi Provincial People's Hospital, Taiyuan 030001, China \\ ${ }^{2}$ Department of Neurosurgery, Tongji Medical College, Huazhong University of Science and Technology, Wuhan 430030, China \\ ${ }^{3}$ Department of Neurosurgery, Liyuan Hospital, Tongji Medical College, Huazhong University of Science and Technology, Wuhan \\ 430077, China \\ ${ }^{4}$ Department of Neurosurgery, Wuhan Central Hospital, Tongji Medical College, Huazhong University of Science and Technology, \\ Wuhan 430014, China \\ Correspondence should be addressed to Gangli Zhang; zhanggangli1973@163.com
}

Received 13 May 2018; Accepted 23 May 2018; Published 23 August 2018

Copyright (C) 2018 Hongming Ji et al. This is an open access article distributed under the Creative Commons Attribution License, which permits unrestricted use, distribution, and reproduction in any medium, provided the original work is properly cited.

\begin{abstract}
In the article titled "Determination of Serum Lost Goodwill Target Proteome in Patients with Severe Traumatic Brain Injury" [1], there was an incomplete description of how the results related to our earlier publications. The predictive value of LGT in TBI was also overestimated. We apologise for this and explain below the relationship between our articles, why we classified the patients as we did, and the use of the grants for this research.
\end{abstract}

\section{Previous Articles}

Our earlier work was discussed as follows, which was not sufficient: "Ren et al. [11] reported that the LGT proteome was produced under the pathologic condition of TBI patients, and the abundance of LGT proteome is closely associated with pathogenetic condition and prognosis of TBI patients; the LGT proteome may play an important role in predicting pathogenetic condition and prognosis of TBI patients."

Our three earlier articles also studied serum LGT expression as a potential biomarker in traumatic brain injury. A summary of our four articles is listed in Table 1.

Comparing all types of patients, we believed that the LGT proteome is more important in severe traumatic brain injury (TBI). Thus, in later studies and case collection we focused on severe TBI. Some patients/data were shared between the articles, though there was a different emphasis for each study. The present article [1] contains the final summary of severe TBI.

In the section "The Innovation", we stated "Serum LGT proteome was detected by surface enhanced laser desorption/ionisation time-of-flight mass spectrometer (SELDITOF-MS). The LGT proteome presents in the serum of severe TBI patients. The abundance diversity of LGT proteome is intimately associated with pathogenetic condition of TBI patients. Serum LGT proteome may be used as a promising marker for evaluating severity of severe TBI." We did not intend to exaggerate the research results, but this overstated the originality of the analysis, as Professor Yi Pei had already used SELDI-TOF-MS technology to detect the LGT proteome [5] and our earlier work using Proteome Dynamic Change found that LGT expression was present in the serum of severe TBI patients. The LGT proteome was found in patients with cancer in Professor Pei's study, but this work studied the abundance of the LGT proteome in critical patients without neoplasms and extended our earlier work on severe TBI.

\section{Patient Grouping}

The standard classification of TBI on the GCS is severe with $3-8$, moderate with $9-12$, and mild with $12-14$. In this 
TABLE 1: A comparison of the articles by Zhang and colleagues on serum LGT proteome in TBI.

\begin{tabular}{|c|c|c|c|c|}
\hline Title & $\begin{array}{l}\text { The expression and } \\
\text { prognostic of serum LGT } \\
\text { proteome in patients with } \\
\text { traumatic brain injury } \\
\text { [in Chinese] [2] }\end{array}$ & $\begin{array}{l}\text { The Clinical Significance of } \\
\text { Changes of the Serum LGT } \\
\text { Proteome in Patients with } \\
\text { traumatic brain injury [in } \\
\text { Chinese] [3] }\end{array}$ & $\begin{array}{l}\text { The alteration of serum } \\
\text { LGT proteome in patients } \\
\text { with severe traumatic brain } \\
\text { injury and its prognostic } \\
\text { value [in Chinese] [4] }\end{array}$ & $\begin{array}{c}\text { Determination of Serum } \\
\text { Lost Goodwill Target } \\
\text { Proteome in } \\
\text { Patients with Severe } \\
\text { Traumatic Brain Injury [1] }\end{array}$ \\
\hline Journal & $\begin{array}{l}\text { Chinese Remedies \& } \\
\text { Clinics } \\
\end{array}$ & $\begin{array}{c}\text { Chinese Remedies \& } \\
\text { Clinics } \\
\end{array}$ & Chin J Exp Surg & $\begin{array}{l}\text { BioMed Research } \\
\text { International }\end{array}$ \\
\hline Publication date & February 2011 & October 2010 & June 2011 & July 2015 \\
\hline Enrolled cases & 105 cases with TBI & 69 cases with TBI & 84 cases with severe TBI & 96 cases with severe TBI \\
\hline $\begin{array}{l}\text { Period of case } \\
\text { collection }\end{array}$ & March 2006 to July 2008 & $\begin{array}{c}\text { April } 2007 \text { to February } \\
2008\end{array}$ & March 2006 to July 2008 & March 2006 to July 2009 \\
\hline Patient groups & $\begin{array}{c}\text { TBI: } \\
\text { GCS 3-8 } \\
\text { GCS 8-12 } \\
\text { GCS 12-15 }\end{array}$ & $\begin{array}{c}\text { TBI: } \\
\text { GCS 3-8 } \\
\text { GCS 8-12 } \\
\text { GCS 12-15 }\end{array}$ & $\begin{array}{l}\text { Severe TBI: } \\
\text { GCS 3-5 } \\
\text { GCS 6-8 }\end{array}$ & $\begin{array}{l}\text { Severe TBI: } \\
\text { GCS 3-5 } \\
\text { GCS 6-8 }\end{array}$ \\
\hline $\begin{array}{l}\text { Research } \\
\text { highlights }\end{array}$ & $\begin{array}{c}\text { The factors affecting the } \\
\text { surgery, patients in articulo } \\
\text { mortis }\end{array}$ & $\begin{array}{l}\text { The relevance of abundance } \\
\text { of LGT to prognosis }\end{array}$ & $\begin{array}{c}\text { Abundance of LGT, } \\
\text { APACHE II scores and } \\
\text { prognosis }\end{array}$ & $\begin{array}{l}\text { The types and locations of } \\
\text { TBI, and the survival / } \\
\text { outcome of TBI patients }\end{array}$ \\
\hline
\end{tabular}

GCS $=$ Glasgow Coma Score .

study, the severe TBI group was divided into severe and extraordinarily severe, based on $[6,7]$ in which severe TBI was divided into two groups, as described in [8]: "The ability of the Glasgow Coma Scale (GCS) to define the severity of traumatic brain injury (TBI), as well as its widespread acceptance and application in neurological assessment of both preclinical and clinical phases, allows for comparison between different studies and provides a sound basis for quality-patient-management in such cases.”

\section{Survival Analysis}

In this study, we investigated the expression of LGT proteome at two weeks and we found that the proteome of patients who later died was increased. Death directly due to brain injury usually occurs within two weeks, and after two weeks it may be attributed to a variety of serious complications and might be unrelated to the primary intracranial lesions. The specific reasons need to be further studied, as the patients' complications and long-term cause of death were not recorded.

\section{Acknowledgments}

The grant from Medical Science and Technology Research Projects of Health Department of Hubei Province (JX4B42) was for research into neuron-specific enolase, $S 100 \beta$ protein, and C-reactive protein reported in the article "Determination of Serum S-100 $\beta$ Protein and CRP in Patients with Severe Traumatic Brain Injury." It was also used to support the present research on LGT. The grants from the National Science Foundation of China (30901774) and National Science Foundation of Shanxi (2014011038-2) were made for basic research in glioma, respectively, "Role and Mechanism of hHSS1 Expression Loss Promoting Glioblastoma Multiforme EMT and Angiogenic Mimicry VM" http://www .sxinfo.gov.cn/u/cms/www/201407/15104949vmjn.xls and "Dual-Targeted Killing of Human Glioblastoma Blood Vessels and Mimic Blood Vessels Mediated by HighPerformance Chitosan Nanoparticles-Mediated Immunotoxin" http://pubsci.com/nsfc/index.php?projectname=高性 能壳聚糖纳米微囊介导免疫毒素对人脑胶质母细胞瘤血 管及其“拟态血管”的双重靶向杀伤研究. These research projects were carried out at the same time at the Department of Neurosurgery and shared some laboratory consumables and reagents.

\section{Supplementary Materials}

The original data is included as Supplementary Materials. (Supplementary Materials)

\section{References}

[1] H. Ji, C. Hu, G. Zhang et al., "Determination of Serum Lost Goodwill Target Proteome in Patients with Severe Traumatic Brain Injury," BioMed Research International, vol. 2015, Article ID 183821, 7 pages, 2015.

[2] Z. Gang-li, R. Jin-rui, J. Hong-ming, and Z. Han-wei, "The expression and prognostic significance of serum LGT proteome in patients with traumatic brain injury," Chinese Remedies Clinics, vol. 2, pp. 125-127, 2011.

[3] R. Jinrui, Z. Gangli, J. Hongmin, and Z. Hanwei, “The clinical significance of changes of the sermn LGT proteome in patients with traumatic brain injury:a pilot study," Chinese Remedies Clinics, vol. 10, pp. 1095-1097, 2010.

[4] R. Jinrui, Z. Gangli, J. Hongming et al., "Changes of serum LGT proteome in patients with severe craniocerebral injury and its relationship with prognosis," Chinese Journal of Experimental Surgery, vol. 28, pp. 1001-1002, 2011.

[5] Y. Pei, S. Guo, and Q. Wang, "The first observation of the clinical significance of LGT proteome for cancer patients," Cancer Research and Clinic, vol. 17, no. 3, pp. 156-158, 2005. 
[6] G. Teasdale and B. Jennett, "Assessment of coma and impaired consciousness. A practical scale," The Lancet, vol. 2, no. 7872, pp. 81-84, 1974.

[7] C. K. Lackner, M. Ruppert, M. Lazarovici, and E. Stolpe, "Anwenderperformanz und -variabilität der Glasgow-KomaSkala," Notfall \& Rettungsmedizin, vol. 5, no. 3, pp. 173-185, 2002.

[8] P. Sefrin, M. Brandt, and M. Kredel, "Preclinical care of children with traumatic brain injury (TBI)," German Medical Science, vol. 2,2004 




The Scientific World Journal
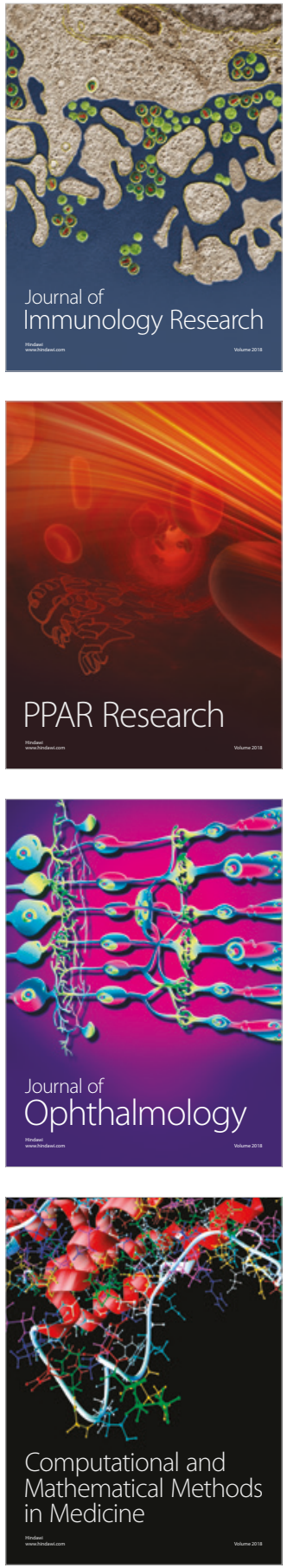



Gastroenterology Research and Practice

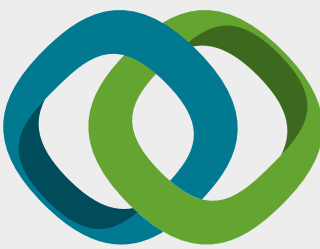

\section{Hindawi}

Submit your manuscripts at

www.hindawi.com
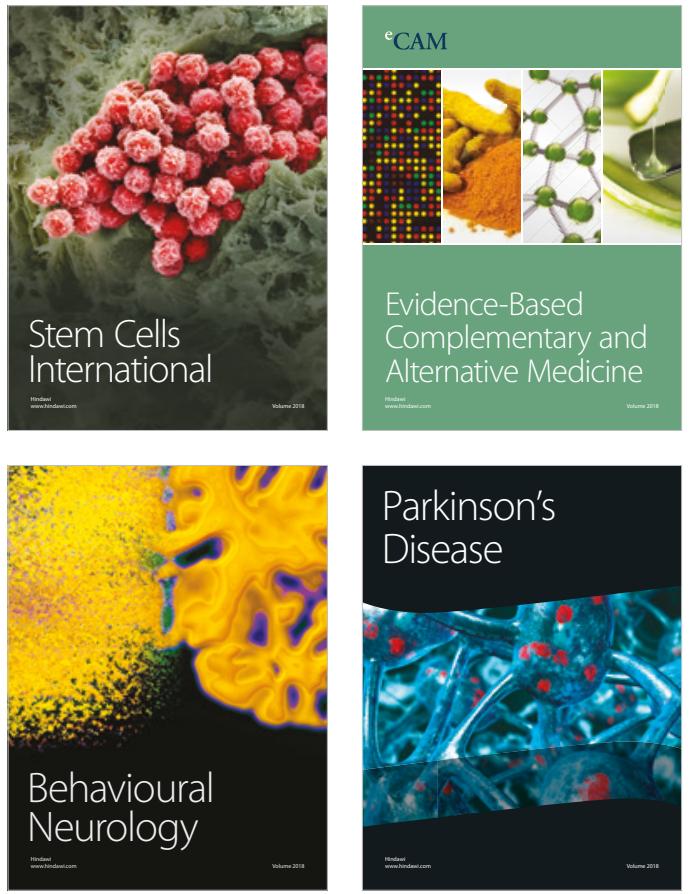

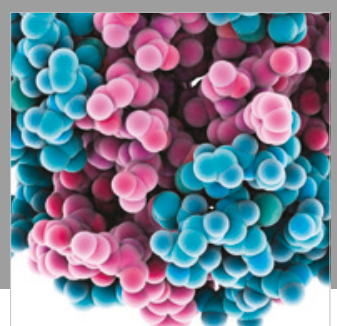

ournal of

Diabetes Research



Disease Markers
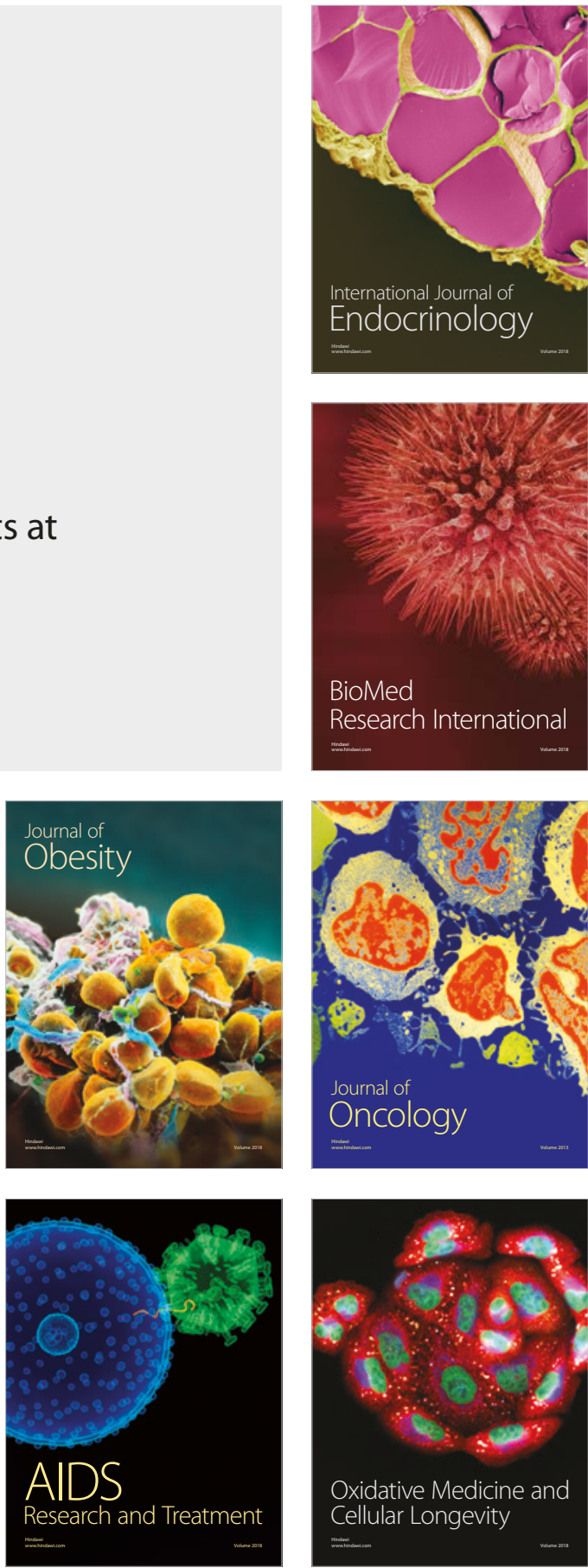